\title{
SYNTHESIS AND ANTIPLASMODIAL ACTIVITY TESTING OF (1)-N-ALKYL- AND (1)-N- BENZYL-6-NITRO-1,10-PHENANTHROLINIUM SALTS AS NEW POTENTIAL ANTIMALARIAL AGENTS
}

\author{
Ruslin Hadanu ${ }^{1, *}$, Sabirin Mastjeh ${ }^{2}$, Jumina $^{2}$, Mustofa $^{3}$, \\ Eti Nurwening Sholikhah ${ }^{3}$, and Mahardika Agus Wijayanti ${ }^{4}$ \\ ${ }^{1}$ Department of Chemistry, Faculty of Teachership and Educational Science, Pattimura University, Poka, Ambon, Indonesia \\ ${ }^{2}$ Department of Chemistry, Faculty of Mathematics and Natural Sciences, Universitas Gadjah Mada, \\ Sekip Utara, Yogyakarta, Indonesia \\ ${ }^{3}$ Department of Pharmacology and Toxicology, Faculty of Medicine, Universitas Gadjah Mada, \\ Sekip Utara, Yogyakarta, Indonesia \\ ${ }^{4}$ Department of Parasitology, Faculty of Medicine, Universitas Gadjah Mada, \\ Sekip Utara, Yogyakarta, Indonesia
}

Received May 26, 2011; Accepted September 2011

\begin{abstract}
The synthesis of 5-nitro-1,10-phenanthroline hydrate 2 derivatives from 1,10-phenanthroline monohydrate as starting material has been carried out. The 5-nitro-1,10-phenanthroline hydrate 2 was obtained through nitration reaction using $\mathrm{H}_{2} \mathrm{SO}_{4}$ and $\mathrm{HNO}_{3}$ as catalyst and reagent, respectively. Synthesis of (1)-N-alkyl-6-nitro- and (1)-Nbenzyl-6-nitro-1,10-phenanthrolinium have been prepared using dimethyl sulphate (DMS), diethyl sulphate (DES), benzyl chloride, benzyl bromine, and benzyl iodide. The reagents of benzyl bromine, and benzyl iodide were synthesized from benzyl chloride using $\mathrm{NaBr}$ in ethanol absolute and $\mathrm{Nal}$ in acetone, respectively. The five compounds of 5-nitro-1,10-phenanthroline hydrate 2 derivatives were conducted to evaluate the in vitro antiplasmodial activity. The in vitro antiplasmodial was evaluated on strains of Plasmodium falciparum FCR-3 resistant chloroquine and D10 sensitive chloroquine. The $50 \%$ inhibition concentration $\left(I C_{50}\right)$ of the five compounds ranged from $2.41 \pm 1.41$ to $0.07 \pm 0.01 \mu \mathrm{M}$. The results showed that the (1)- $N$-benzyl-6-nitro-1,10-phenanthrolinium iodide had highest antiplasmodial activity.
\end{abstract}

Keywords: 5-nitro-1,10-phenanthroline hydrate; P. falciparum; antimalarial; antiplasmodial

\section{ABSTRAK}

Telah dilakukan sintesis turunan senyawa 5-nitro-1,10-fenantrolin hidrat 2 dari bahan dasar 1,10-fenantrolin monohidrat. Senyawa 5-nitro-1,10-fenantrolin diperoleh melalui reaksi nitrasi menggunakan katalis dan reagen berturut-turut $\mathrm{H}_{2} \mathrm{SO}_{4}$ dan $\mathrm{HNO}_{3}$. Sintesis senyawa (1)-N-alkil-6-nitro- dan (1)-N-benzil-6-nitro-1,10-fenantrolinium dilakukan menggunakan pereaksi-pereaksi dimetil sulfat (DMS), dietil sulfat (DES), benzil klorida, benzil bromida, dan benzil iodida. Reagen benzil bromida dan benzil iodida telah disintesis dari bahan dasar benzil klorida menggunakan reagen berturut-turut $\mathrm{NaBr}$ dalam etanol dan $\mathrm{Nal}$ dalam aseton. Pada kelima senyawa turunan 5nitro-1,10-fenantrolin 2 tersebut telah dilakukan uji aktivitas antiplasmodium secara in vitro terhadap strain resistan klorokuin Plasmodium falciparum FCR-3 dan strain sensitif klorokuin D10. Nilai konsentrasi penghambatan 50\% $\left(I C_{50}\right)$ dari kelima senyawa tersebut berkisar dari 2,41 $\pm 1,41$ sampai 0,07 $\pm 0,01 \mu \mathrm{M}$. Dari hasil uji aktivitas tersebut ditunjukan bahwa senyawa (1)-N-benzil-6-nitro-1,10-fenantrolinium iodida mempunyai aktivitas antiplasmodium yang paling tinggi.

Kata Kunci: 5-nitro-1,10-fenantrolin hidrat; P. falciparum; antimalaria; antiplasmodium

\section{INTRODUCTION}

Malaria is the main health problems in subtropical and tropical countries. There are 105 countries in the world at malaria endemic and more than 500 million

* Corresponding author. Tel/Fax : +62-85228447288

Email address : ruslin_hadanu@yahoo.com

Ruslin Hadanu et al.

cases or more than 2.7 million deaths from malaria each year [1-3]. In Indonesia, malaria is still a health problem, especially in east Indonesia. In the year 2003 the Annual Parasitemia Incidence (API) have 175.558 cases, and the annual malaria incidence more than 


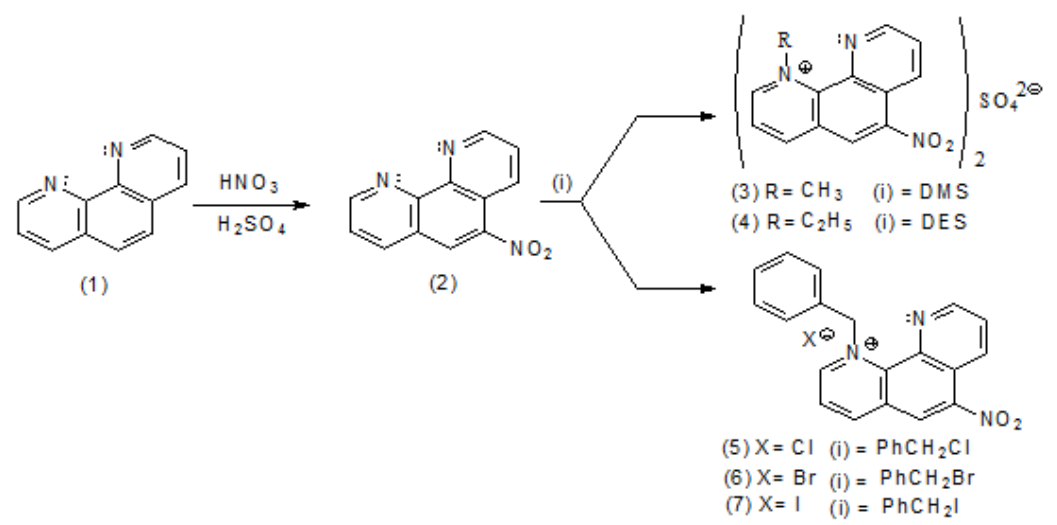

Fig 1. The reaction scheme of synthesis of 5-nitro-1,10-phenanthroline 2 derivatives

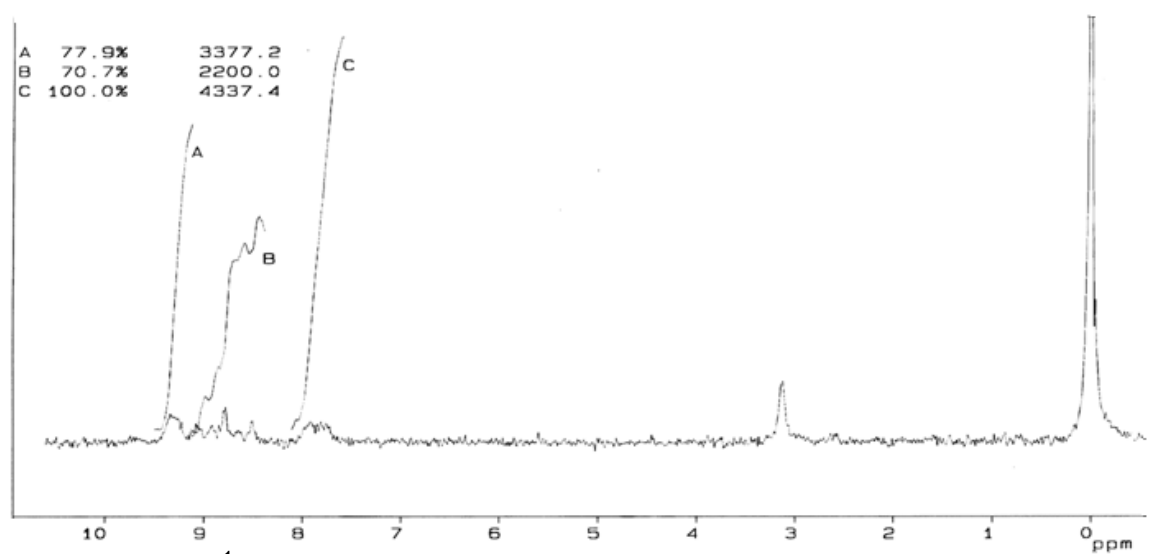

Fig 2. The ${ }^{1} \mathrm{H}-\mathrm{NMR}$ spectrum of 5-nitro-1,10-phenanthroline 2 compound

2.48 million and there are 211 people deaths among 227.5 million people of Indonesian [4]. Malaria is one of the most important diseases of the developing world, killing 1-3 million people and causing disease in 300-500 million people annually [5-7].

The traditional remedies are no longer effective and the incidence of malarial by $P$. falciparum, the most dangerous species of parasite, continues to grow, while some traditional drugs such as chloroquine and its congeners are losing their activity due to the increasing multi drug resistance [8-9]. Therefore, it is essential to find new drugs of antimalarial having a pharmacological activity higher that of currently available drugs of antimalarial. In this connection, Quantitative Structure Activity Relationship (QSAR) analysis plays an important role to minimize trial and error in designing new antimalarial drugs.

In our research a few years ago, we focused to synthesize and to evaluate of antiplasmodial activity of 1,10-phenanthroline derivatives. In continuation of these studies, we have reported the results of the synthesis and determination of biological activity of compounds type (1)- $N$-alkyl-and (1)- $N$-benzyl-1,10-phenanthrolinium [10]. Yapi et al. [8] have synthesized diaza-analogs of phenanthrene by substituting the two nitrogen atoms in the phenanthrene skeleton. Antiplasmodial activity of series of diaza-analogs of phenanthrene derived from 3-amino-, 5-amino-, 6-amino-, 8-aminoquinoline and 5 -isoquinoline showed that among the molecules evaluated the 1,10-phenanthroline skeleton was the most active compound in vitro on both chloroquineresistant (FCB1) and chloroquine-sensitive (Nigerian) strain with an $\mathrm{IC}_{50}$ of about $0.13 \mu \mathrm{M}$. Based on the skeleton, Mustofa, et al. [11] have also synthesized thirteen derivatives of 1,10-phenanthroline and evaluated the in vitro antiplasmodial activity [8] and their Quantitative Structure Activity Relationship (QSAR) [11]. The results of QSAR analysis of six new compounds 1,10-phenanthroline derivatives have the best theoretical activity, so that it is recommended to synthesize and to evaluate through experiments in the laboratory.

The antiplasmodial activity of (1)- $N$-alkyl- and (1)- $N$-benzyl-1,10-phenanthrolinium showed that (1)-Nmethyl-1,10-phenanthrolinium sulphate, (1)- $N$-ethyl1,10-phenanthrolinium sulphate, (1)- $N$-benzyl-1,10phenanthrolinium chloride, (1)- $N$-benzyl-1,10phenanthrolinium bromide and (1)- $N$-benzyl-1,10phenanthrolinium iodide were active against $P$. falciparum FCR3 with an $\mathrm{IC}_{50} 0.18 \pm 0.01-0.10$ 
$\pm 0.04 \mu \mathrm{M}$ and D10 strains with an $\mathrm{IC}_{50} 0.74 \pm 0.20-0.34$ $\pm 0.07 \mu \mathrm{M}[10]$.

Recently, the analysis of Quantitative Structure Activity Relationship (QSAR) against the series of sixteen compounds of 1,10-phenanthroline monohydrate 1 derivatives were conducted [12]. In this analysis of quantitative structure activity relationship was obtained the best QSAR equation model:

In $1 / I C_{50}=3.732-(5.098) C_{5}+(7.051) q C_{7}+(36.696)$ $\mathrm{qC}_{9}+(41.467) \mathrm{qC}_{11}-(135.497) \mathrm{qC}_{12}+(0.332) \mu-$ $(0.170) \alpha-(0.757) \log P$.

The QSAR equation model above was used to modeling the 5-nitro-1,10-phenanthroline hydrate $\mathbf{2}$ derivatives. The results of the QSAR analysis has found the best theoretical antiplasmodial activity of new 5-nitro1,10-phenanthroline hydrate 2 compounds i.e: (1)- $\mathrm{N}$ methyl-6-nitro-1,10-phenanthrolinium sulphate 3 ( $\left(\mathrm{IC}_{50}\right.$ : $0.018 \mu \mathrm{M}), \quad(1)-N$-ethyl-6-nitro-1,10-phenanthrolinium sulphate 4 ( $\left.\mathrm{IC}_{50}: 0.017 \mu \mathrm{M}\right),(1)-N$-benzyl-6-nitro-1,10phenanthrolinium chloride 5 ( $\left.\mathrm{IC}_{50}: 0.103 \mu \mathrm{M}\right),(1)-N-$ benzyl-6-nitro-1,10-phenanthrolinium bromide 6 ( $\left(\mathrm{IC}_{50}\right.$ : $0.103 \mu \mathrm{M}), \quad$ and (1)- $N$-benzyl-6-nitro-1,10phenanthrolinium iodide $7\left(\mathrm{IC}_{50}: 0.103 \mu \mathrm{M}\right)$.

Based on the value of theoretical antiplasmodial activity above, the five new compounds of 5 -nitro-1,10phenanthroline hydrate $\mathbf{2}$ derivatives have been recommended to synthesize and to evaluate of antiplasmodial activity in this research. The strategy of addition the nitro functional group on the 1,10phenanthroline skeleton was used of $\mathrm{H}_{2} \mathrm{SO}_{4}$ and $\mathrm{HNO}_{3}$ as reagent. The reactions condition and the results of synthesis of 5-nitro-phenanthroline hydrate 2 derivatives were presented in Fig. 1. Furthermore, compounds of the product (1)- $N$-alkyl- and (1)- $N$-benzyl-5-nitro-1,10fenantrolinium were synthesized from 5-nitro-1,10phenanthroline hydrate $\mathbf{2}$ through alkylation and benzylation reaction using dimethyl sulfate (DMS), diethyl sulfate (DES), benzyl chloride, benzyl bromide and benzyl iodide, respectively.

\section{EXPERIMENTAL SECTION}

\section{Materials}

The 1,10-phenanthroline hydrate p.a. (Merck), dimethyl sulphate (DMS) p.a. (Merck), dimethyl sulphate (DES) p.a. (Merck), benzyl chloride p.a. (Merck), fuming nitric acid p.a. (Merck), $\mathrm{H}_{2} \mathrm{SO}_{4} 99.8 \%$ p.a. (Merck), $\mathrm{HCl}$ p.a. (Merck), $\mathrm{NaOH}$ p.a. (Merck), $\mathrm{NaBr}$ p.a. (Merck), $\mathrm{Nal}$ p.a. (Merck), $\mathrm{KOH}$ p.a. (Merck), $\mathrm{Na}_{2} \mathrm{SO}_{4}$ anhydrous p.a. (Merck), $\mathrm{NaHCO}_{3}$ p.a. (Merck), acetone p.a. (Merck), $\mathrm{CH}_{2} \mathrm{Cl}_{2}$ p.a. (Merck), diethyl ether p.a. (Merck), $\mathrm{CHCl}_{3}$ p.a. (Merck), $\mathrm{CCl}_{4}$ p.a. (Merck), dimethyl sulphoxide (DMSO) p.a. (Merck), $\mathrm{N}_{2}$ gas, TLC plat, silica gel, hexane p.a. (Merck), and benzene p.a. (Merck).

\section{Instrumentation}

In general, the melting points of compounds were determined on melting point electrothermal 9100 . The spectrum of structures compound measurements were taken using the following instruments: FTIR spectrums were taken on Shimadzu FTIR-8201 PC; ${ }^{1} \mathrm{H}-\mathrm{NMR}$ spectrums were obtained on JEOL $60 \mathrm{MHz}$ and JEOL $500 \mathrm{MHz}$. MS spectrums were recorded on GC-MS Shimadzu QP 5000.

\section{Procedure}

Synthesis of 5-nitro-1,10-phenanthroline hydrate (2) The 1,10-phenanthroline monohydrate 1 (1.10 g; $5.5 \mathrm{mmol}$ ) was dissolved in $30 \mathrm{~mL}$ of concentrated $\mathrm{H}_{2} \mathrm{SO}_{4}$. The $15 \mathrm{~mL}$ of fuming nitric acid were added dropwise to this stirred solution, while the temperature was maintained between $160-170{ }^{\circ} \mathrm{C}$. The mixture was kept at $160-170^{\circ} \mathrm{C}$ during two hours, and subsequently poured into ice water. The $\mathrm{pH}$ of this aqueous solution was adjusted to $\mathrm{pH}=3$ by adding a sodium hydroxide solution $(\mathrm{NaOH} 10 \mathrm{~N})$. The precipitate of product was filtered off, washed with water and dried in vacuo. When desired, 5-nitro-1,10-phenanthroline hydrate can be purified by recrystallization in isopropanol. The 5nitro-1,10-phenanthroline hydrate was isolated as brown solid compound $(1.37 \mathrm{~g} ; 99.49 \%)$, m.p.: $195^{\circ} \mathrm{C}$. FT-IR $\left(\mathrm{KBr}, \quad \mathrm{v} ; \mathrm{cm}^{-1}\right): 3409.9(\mathrm{O}-\mathrm{H}$ from hydrogen bonding), 3055.0 and $3008.7\left(\mathrm{C}_{\mathrm{sp} 2}-\mathrm{H}\right), 2873.7\left(\mathrm{C}_{\mathrm{sp} 3}-\mathrm{H}\right)$, 1620.1 and 1527.5 (asymmetry stretch of $\mathrm{NO}_{2}$ ), 1585.4 and 1500.0 ( $\mathrm{C}=\mathrm{C}$ aromatic), 1350.1 (symmetry stretch of $\mathrm{NO}_{2}$ ), 1176.5 (C-N bonding). ${ }^{1} \mathrm{H}-\mathrm{NMR}$ (DMSO-d6; $500 \mathrm{MHz}) \delta(\mathrm{ppm}): 9.3\left(2 \mathrm{H}, \mathrm{m}, \mathrm{H}_{\mathrm{A}}\right), 9.0-8.6(2 \mathrm{H}, \mathrm{m}$, $\left.\mathrm{H}_{\mathrm{B}}\right)$, 8.0-7.6 $\left(2 \mathrm{H}, \mathrm{m}, \mathrm{H}_{\mathrm{C}}\right), 3.0\left(\mathrm{H}_{2} \mathrm{O}\right.$; s; hydrogen bonding); MS (EI) m/z: 225 (M), 195 (M-.NO), 179 (M$\left.\mathrm{NO}_{2}\right), 167$ (195-.CO), $141\left(167-\mathrm{C}_{2} \mathrm{H}_{2}\right), 114(141-\mathrm{HCN})$, and $75\left(114-\mathrm{H}_{2} \mathrm{C}=\mathrm{C}=. \mathrm{CH}\right)$.

\section{Synthesis of benzyl bromide}

Benzyl chloride (5.04 g; $40 \mathrm{mmol}$ ) was added into a solution of $\mathrm{NaBr}(9.0 \mathrm{~g} ; 60 \mathrm{mmol})$ in ethanol absolute $(120 \mathrm{~mL})$. The mixture was stirred in room temperature for $3 \mathrm{~h}$. The solvent was removed by vacuum evaporation, and then the residue was diluted with water $(30 \mathrm{~mL})$, and extracted with $\mathrm{CH}_{2} \mathrm{Cl}_{2}(3 \times 25 \mathrm{~mL})$. The combined organic layers were washed with water ( $2 \times 30 \mathrm{~mL}$ ), dried over $\mathrm{Na}_{2} \mathrm{SO}_{4}$ anhydrous and evaporated to give benzyl bromide compound (yellow liquid, $84.25 \%$ ) and further purification by distillation (b.p $198-199{ }^{\circ} \mathrm{C} ; 80.56 \%$ ). FT-IR (neat, $0, \mathrm{~cm}^{-1}$ ): 3031.9, 2974.0, 740.6; 698.2; 605.6 and $547.7 \mathrm{~cm}^{-1}$. The ${ }^{1} \mathrm{H}-\mathrm{NMR}\left(\mathrm{CDCl}_{3} ; 60 \mathrm{MHz}\right.$; TMS) $\delta: 4.3(2 \mathrm{H}, \mathrm{s}$, $\left.\mathrm{CH}_{2}\right), 7.1-7.4\left(5 \mathrm{H}, \mathrm{m}, \mathrm{H}_{\text {-phenyl }}\right)$. MS (relative intensity) (EI) m/z: $172\left[\mathrm{M}^{+}+2\right], 170\left[\mathrm{M}^{+}\right], 91 ; 65 ; 51 ; 39$. 


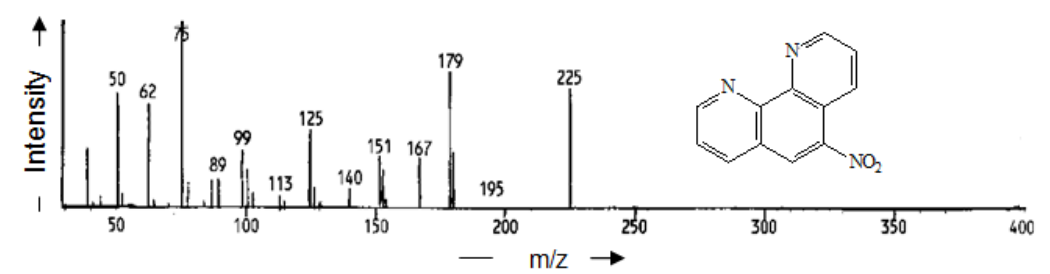

Fig 3. The mass spectrum of 5-nitro-1,10-phenanthroline 2 compound

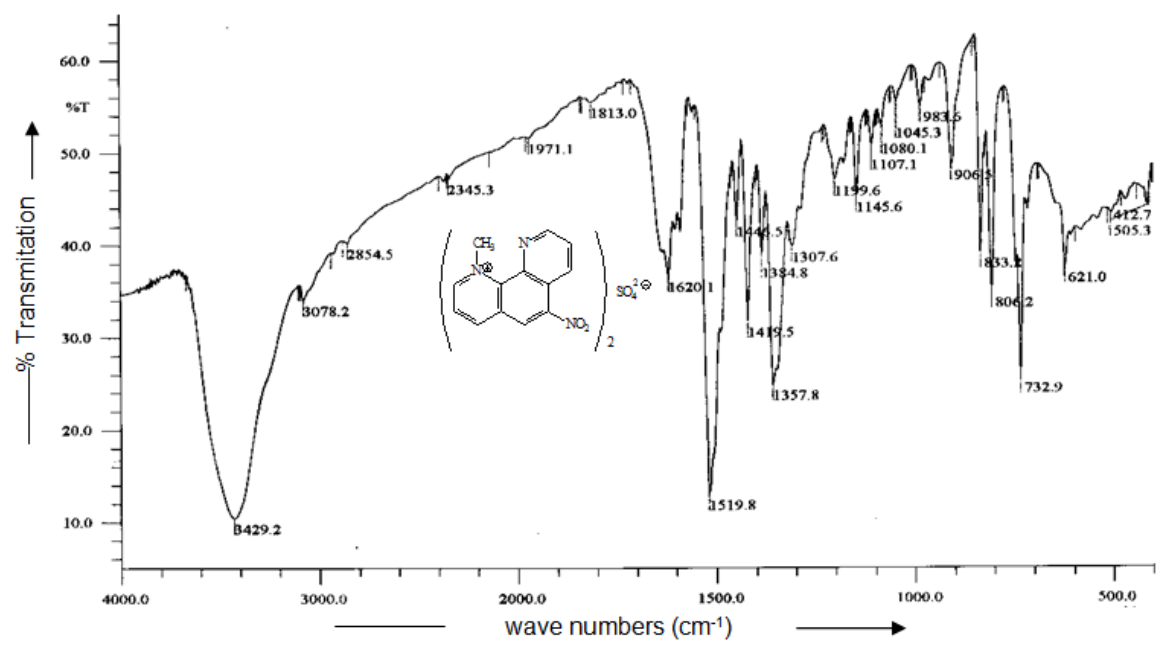

Fig 4. The FTIR spectrum of (1)-N-methyl-6-nitro-1,10-phenanthrolinium sulphate 3 compound

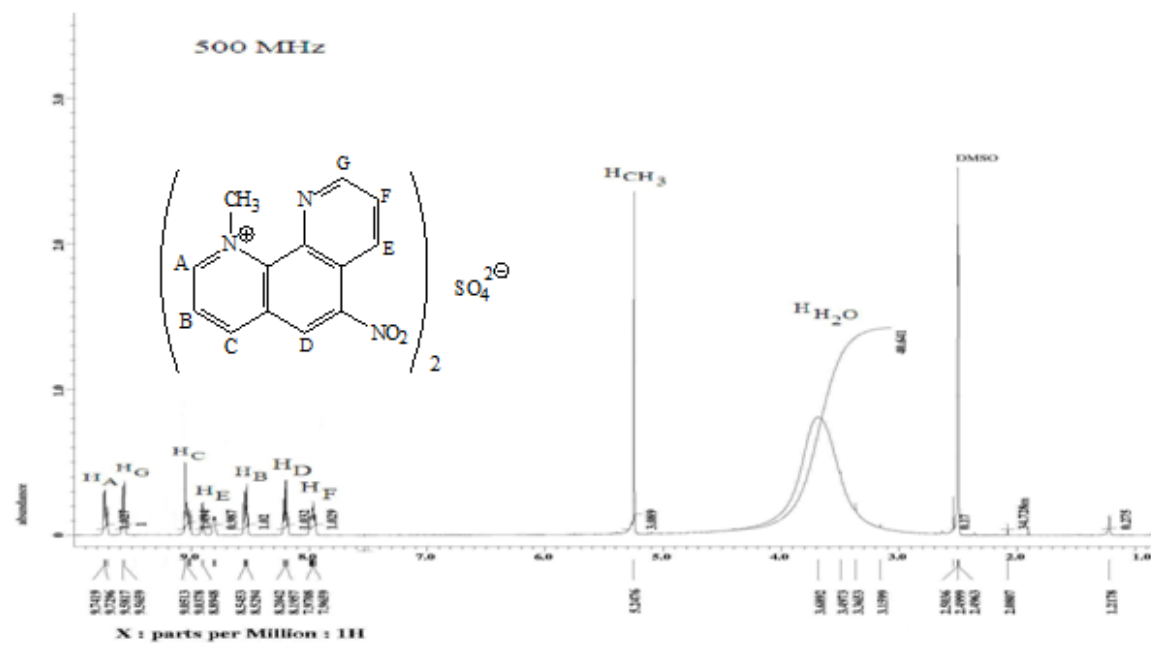

Fig. 5. The ${ }^{1} \mathrm{H}-\mathrm{NMR}$ spectrum of (1)-N-methyl-6-nitro-1,10-phenanthrolinium sulphate 3

\section{Synthesis of benzyl iodide}

A solution of benzyl chloride $(5.04 \mathrm{~g} ; 40 \mathrm{mmol})$ was added into a solution of $\mathrm{Nal}(9.0 \mathrm{~g} ; 60 \mathrm{mmol})$ in acetone $(60 \mathrm{~mL})$. The mixture was stirred in room temperature for $3 \mathrm{~h}$. After evaporation, the residue was diluted with water (30 mL), and extracted with $\mathrm{CH}_{2} \mathrm{Cl}_{2}(3 \times 25 \mathrm{~mL})$. The combined organic layers were washed with water (2 x $70 \mathrm{~mL})$, dried over $\mathrm{Na}_{2} \mathrm{SO}_{4}$ anhydrous and evaporated to give benzyl iodide compound (yellow solid, 97.93\%). FT-IR (neat, $0, \mathrm{~cm}^{-1}$ ): 3028.0, $1600-1500.0,2900.0,1454.2,752.2,694.3,567.0$ and
$540.0 \mathrm{~cm}^{-1} .{ }^{1} \mathrm{H}-\mathrm{NMR}\left(\mathrm{CDCl}_{3} ; 60 \mathrm{MHz}, \mathrm{TMS}\right) \delta: 4.4(2 \mathrm{H}$, $\left.\mathrm{s}, \mathrm{CH}_{2}\right), 7.1-7.5\left(5 \mathrm{H}, \mathrm{m}, \mathrm{H}_{\text {-phenyl }}\right)$. MS (relative intensity) (EI) $\mathrm{m} / \mathrm{z}: 218\left[\mathrm{M}^{+}\right] ; 91 ; 65 ; 51 ; 39$.

\section{Synthesis of (1)-N-methyl-6-nitro-1,10-phenanthro} linium sulphate (3)

A solution of 5-nitro-1,10-phenanthroline hydrate 2 (0.45 g; $2 \mathrm{mmol})$ and DMS (1.26 g; $10 \mathrm{mmol})$ in acetone $(20 \mathrm{~mL})$ was refluxed for $11 \mathrm{~h}$. The resulting mixture was cooled, then the precipitate which formed was filtered, and washed with acetone. Recrystallization 


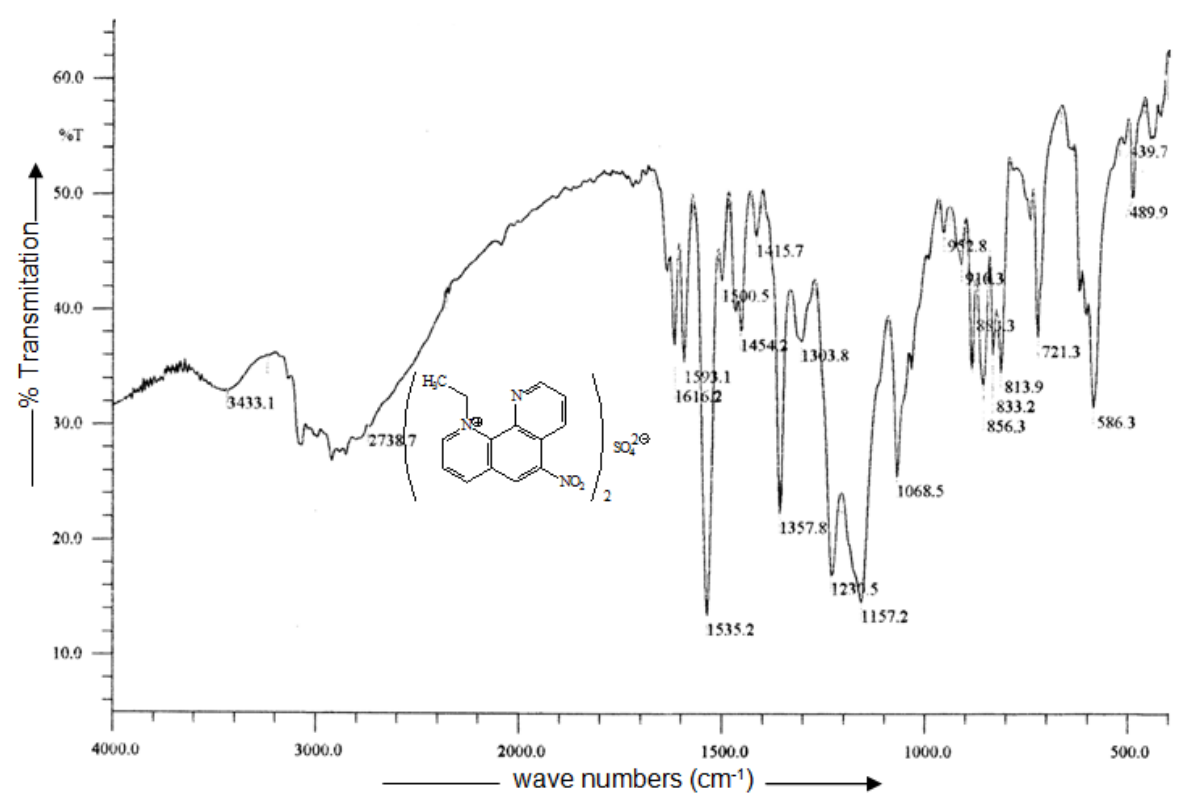

Fig 6. FTIR spectrum of (1)-N-ethyl-6-nitro-1,10-phenanthrolinium sulphate 4 compound

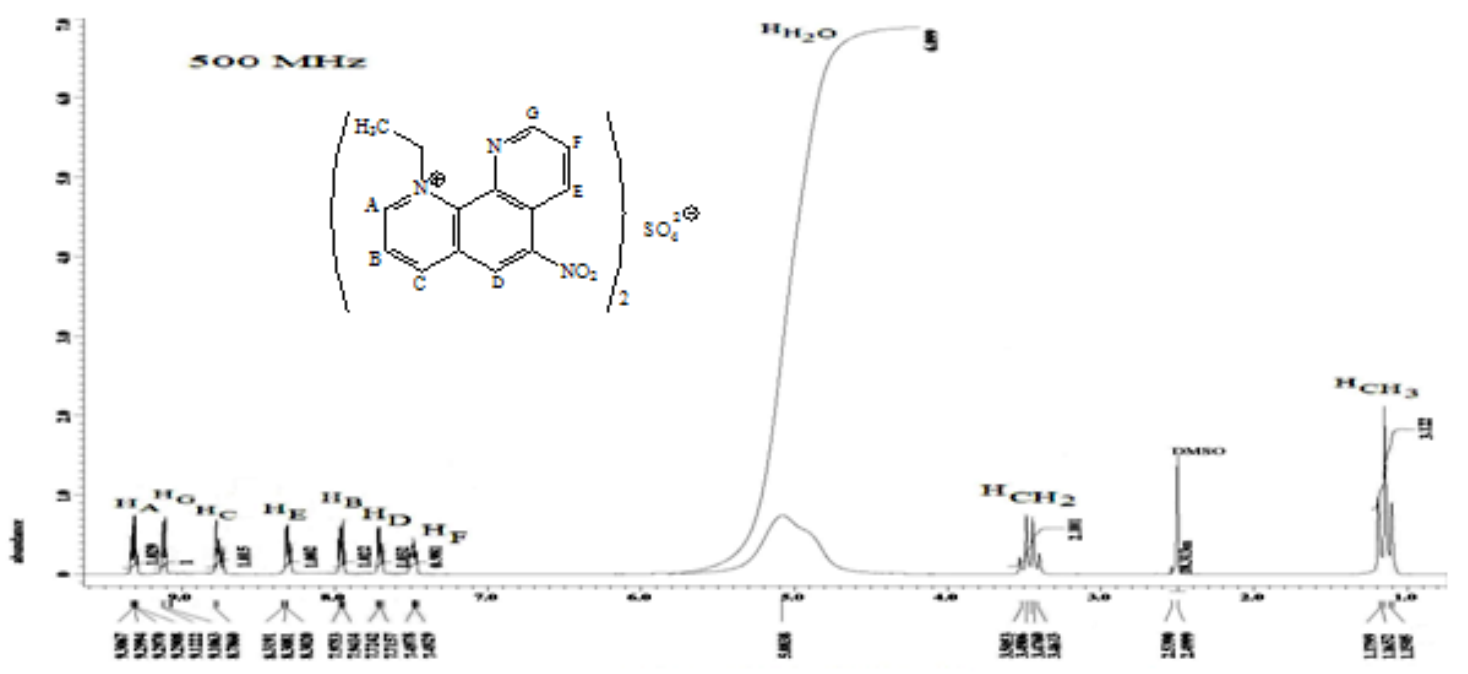

Fig 7. The ${ }^{1} \mathrm{H}-\mathrm{NMR}$ spectrum of (1)-N-ethyl-6-nitro-1,10-phenanthrolinium sulphate 4

of product was conducted with dichloromethane : diethyl ether (1:1) to give white solid compound of (1)-N-methyl6-nitro-1,10-phenanthrolinium sulphate 3 (0.93 g; $81.26 \%$, m.p $192-194{ }^{\circ} \mathrm{C}$ ). The product was characterized by means of IR and ${ }^{1} \mathrm{H}-\mathrm{NMR}$. FT-IR $(\mathrm{KBr}$, $\left.\mathrm{v} ; \mathrm{cm}^{-1}\right)$ : 3429.2 (O-H hydrogen bonding from hydrate), $3078.2\left(\mathrm{C}_{\mathrm{sp} 2}-\mathrm{H}\right), 2854.5\left(\mathrm{C}_{\mathrm{sp} 3}-\mathrm{H}\right), 1620.1$ and 1519.8 (asymmetry stretch of $\mathrm{NO}_{2}$ ), 1600.0 and $1500.0(\mathrm{C}=\mathrm{C}$ aromatic), $1384.8\left(\mathrm{CH}_{3}\right), 1419.5$ and 1357.8 (symmetry stretch of $\mathrm{NO}_{2}$ ), 1199.6 (C-N); ${ }^{1} \mathrm{HNMR}(500 \mathrm{MHz}$, DMSO-d $\left.\mathrm{d}_{6}, \mathrm{TMS}\right) \delta(\mathrm{ppm}):$ 9.74-9.72 $\left(1 \mathrm{H}, \mathrm{s}, \mathrm{H}_{\mathrm{A}}\right), 9.58-$ $9.56\left(1 \mathrm{H}, \mathrm{s}, \mathrm{H}_{\mathrm{G}}\right), 9.05-9.03\left(1 \mathrm{H}, \mathrm{s}, \mathrm{H}_{\mathrm{C}}\right), 8.89\left(1 \mathrm{H}, \mathrm{s}, \mathrm{H}_{\mathrm{E}}\right)$, 8.54-8.52 $\left(1 \mathrm{H}, \mathrm{s}, \mathrm{H}_{\mathrm{B}}\right), 8.20-8.19\left(1 \mathrm{H}, \mathrm{s}, \mathrm{H}_{\mathrm{H}}\right), 7.97-7.96$ $\left(1 \mathrm{H}, \mathrm{s}, \mathrm{H}_{\mathrm{D}}\right), 5.25\left(3 \mathrm{H}, \mathrm{s}, \mathrm{CH}_{3}\right)$, and $3.69\left(\mathrm{H}_{2} \mathrm{O}, \mathrm{s}\right.$; hydrogen bonding).

\section{Synthesis of (1)-N-ethyl-6-nitro-1,10-phenanthro linium sulphate (4)}

A solution of 5-nitro-1,10-phenanthroline hydrate 2 compound $(0.45 \mathrm{~g} ; 2 \mathrm{mmol}$ ) and DES (1.54 g; 10 $\mathrm{mmol})$ in acetone $(25 \mathrm{~mL})$ was refluxed for $12 \mathrm{~h}$. The resulting mixture was cooled, then the precipitate which formed was filtered, and washed with acetone. Recrystallization of product was conducted with dichloromethane : diethyl ether $(1: 1)$ to give white solid compound of (1)- $N$-ethyl-6-nitro-1,10-phenanthrolinium sulphate $\left(0.93 \mathrm{~g} ; 76.09 \%\right.$; m.p $\left.206-207^{\circ} \mathrm{C}\right)$. The product 


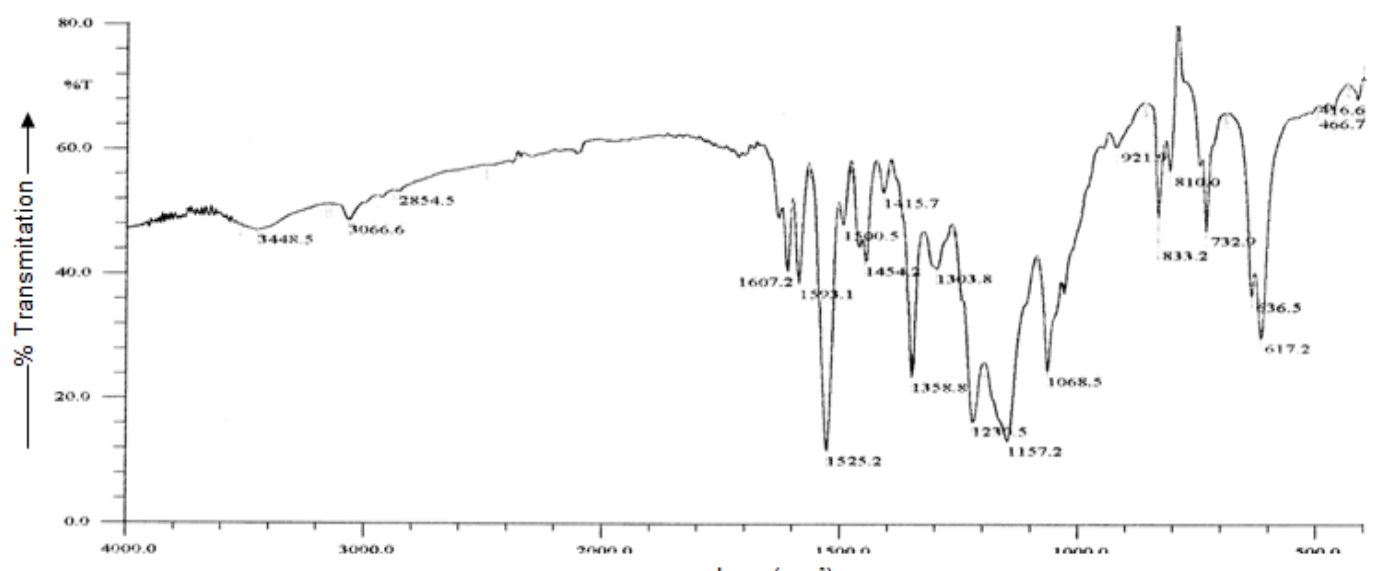

Fig 8. FTIR spectrum of (1)-N-benzyl-6-nitro-1,10-phenanthrolinium chloride 5 compound

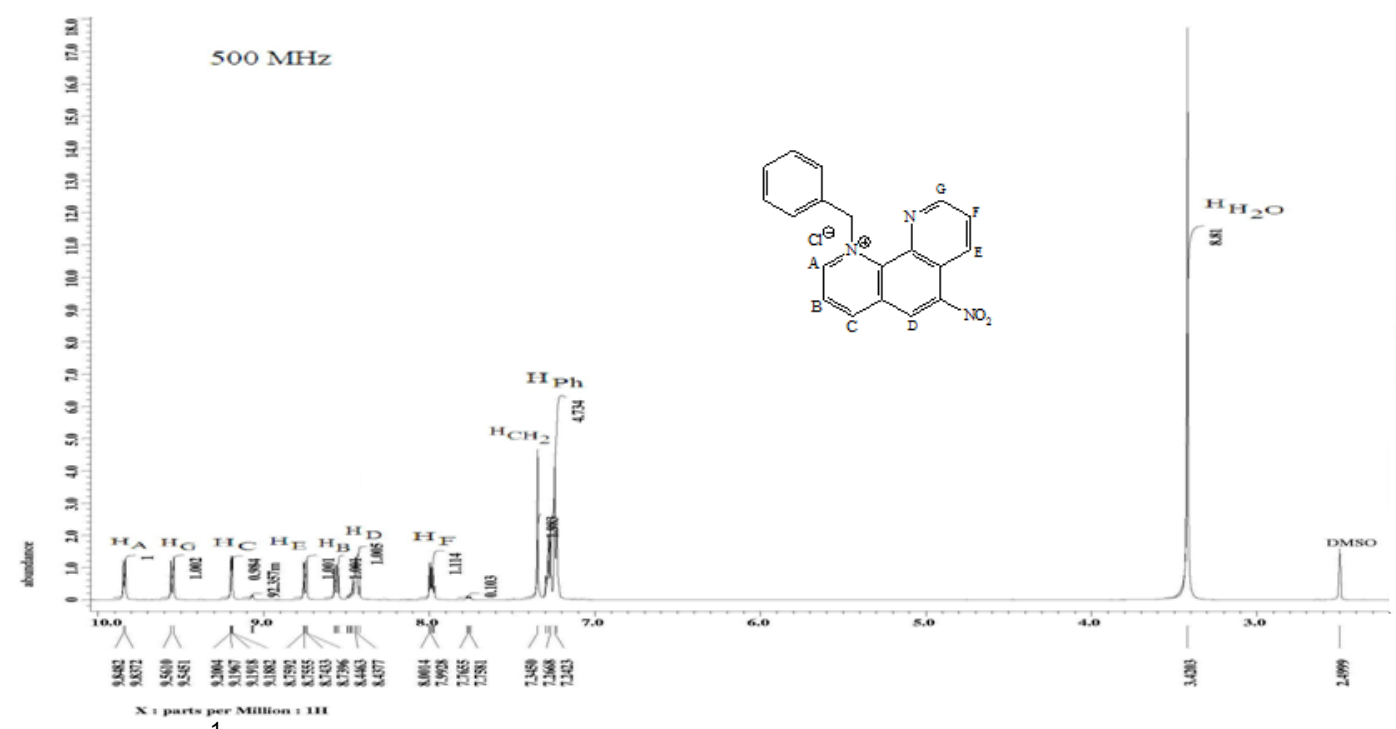

Fig 9. The ${ }^{1} \mathrm{H}-\mathrm{NMR}$ spectrum of (1)-N-benzyl-6-nitro-1,10-phenanthrolinium chloride 5

Table 1. List of chemical shift of ${ }^{1} \mathrm{H}-\mathrm{NMR}$ spectrum from experiment and ChemOffice Ultra 6 software

\begin{tabular}{cccccc}
\hline \multirow{2}{*}{ Proton } & \multicolumn{3}{c}{ Experiment Data } & \multicolumn{2}{c}{ ChemOffice Data } \\
\cline { 2 - 6 } & $\delta(\mathrm{ppm})$ & Amount Proton & Splitting & $\delta(\mathrm{ppm})$ & Estimation Quality \\
\hline $\mathrm{A}$ & $9.74-9.72$ & 1 & singlet & 9.20 & red $=$ rough \\
$\mathrm{G}$ & $9.58-9.56$ & 1 & singlet & 9.02 & blue $=$ good \\
$\mathrm{C}$ & $9.05-9.03$ & 1 & singlet & 9.00 & red $=$ rough \\
$\mathrm{E}$ & 8.89 & 1 & singlet & 8.72 & blue $=$ good \\
$\mathrm{B}$ & $8.20-8.19$ & 1 & singlet & 8.50 & red $=$ rough \\
$\mathrm{D}$ & $7.97-7.96$ & 1 & singlet & 8.23 & blue $=$ good \\
$-\mathrm{CH}_{2-}$ & 7.34 & 3 & singlet & 2.60 & red $=$ rough \\
$\mathrm{Ph}$ & $7.26-7.24$ & 5 & multiplet & $7.06-7.14$ & blue $=$ good \\
$\mathrm{H}_{2} \mathrm{O}$ & 3.69 & Not determined & singlet & 2.00 & red $=$ rough \\
\hline
\end{tabular}

was characterized by means of IR and proton NMR. FT-IR $\left(\mathrm{KBr}, \mathrm{v} ; \mathrm{cm}^{-1}\right)$ : $3433.1(\mathrm{O}-\mathrm{H}$ hydrogen bonding from hydrate), 3050.0-3000.0 $\left(\mathrm{C}_{\mathrm{sp} 2}-\mathrm{H}\right), 2738.7\left(\mathrm{C}_{\mathrm{sp} 3}-\mathrm{H}\right)$, 1616.2 and 1535.2 (asymmetry stretch of $\mathrm{NO}_{2}$ ), 1593.1 and $1500.5\left(\mathrm{C}=\mathrm{C}\right.$ aromatic), $1454.2\left(\mathrm{CH}_{2}\right), 1357.8\left(\mathrm{CH}_{3}\right)$, 1303,8 (symmetry stretch of $\mathrm{NO}_{2}$ ), $1157.2(\mathrm{C}-\mathrm{N})$;
${ }^{1}$ H-NMR (500 MHz, DMSO-d 6 , TMS) $\delta(\mathrm{ppm}):$ 9.31-9.20 $\left(1 \mathrm{H}, \mathrm{m}, \mathrm{H}_{\mathrm{A}}\right), 9.12-9.10\left(1 \mathrm{H}, \mathrm{m}, \mathrm{H}_{\mathrm{G}}\right), 8.79\left(1 \mathrm{H}, \mathrm{m}, \mathrm{H}_{\mathrm{C}}\right)$, 8.32-8.30 (1H, m, $\left.\mathrm{H}_{\mathrm{E}}\right), 7.98-7.94\left(1 \mathrm{H}, \mathrm{m}, \mathrm{H}_{\mathrm{B}}\right), 7.72-7.71$ $\left(1 \mathrm{H}, \mathrm{m}, \mathrm{H}_{\mathrm{D}}\right), 7.50-7.49\left(1 \mathrm{H}, \mathrm{s}, \mathrm{H}_{\mathrm{F}}\right), 5.08\left(\mathrm{H}_{2} \mathrm{O}\right.$; hydrogen bonding from hydrate), 3.51-3.46 $\left(2 \mathrm{H}, \mathrm{m}, \mathrm{CH}_{2}\right)$, and $1.18-1.15\left(2 \mathrm{H}, \mathrm{m}, \mathrm{CH}_{3}\right)$. 


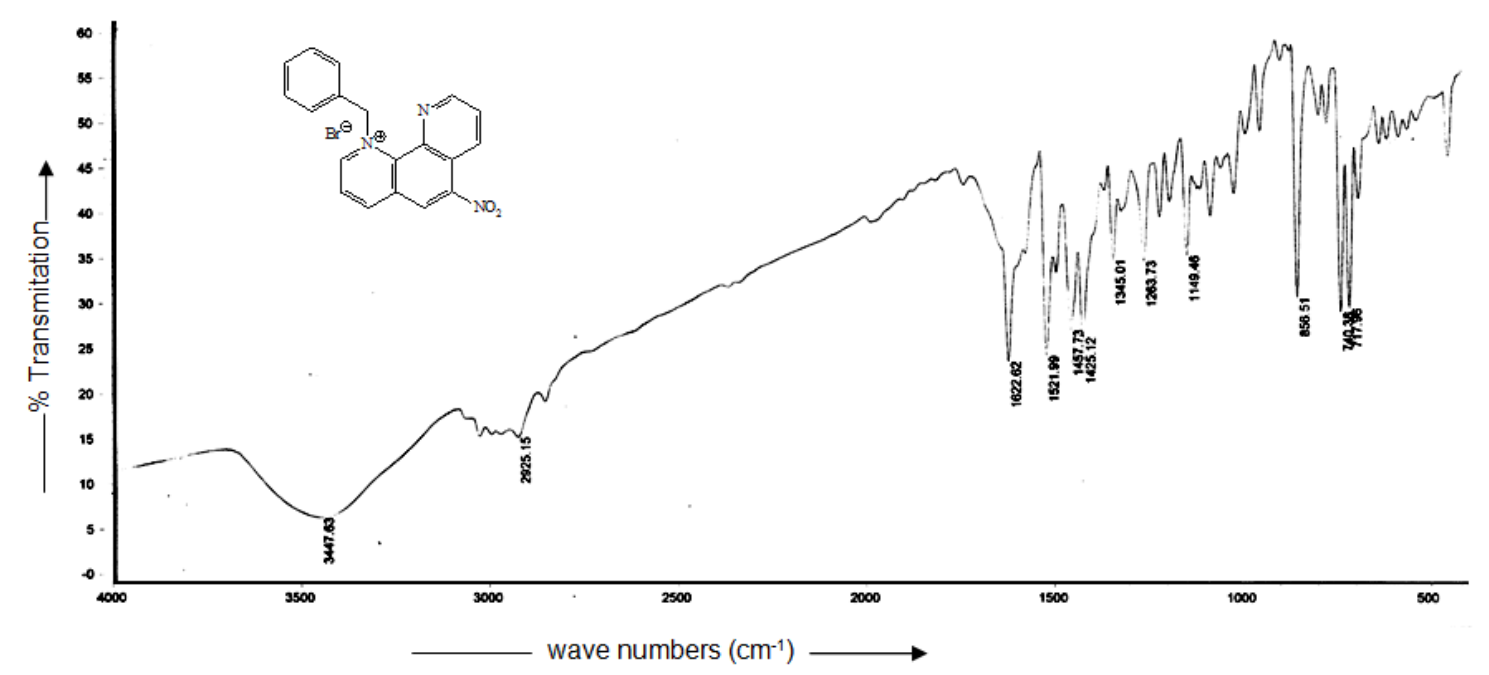

Fig 10. FTIR spectrum of (1)-N-benzyl-6-nitro-1,10-phenanthrolinium bromide 6

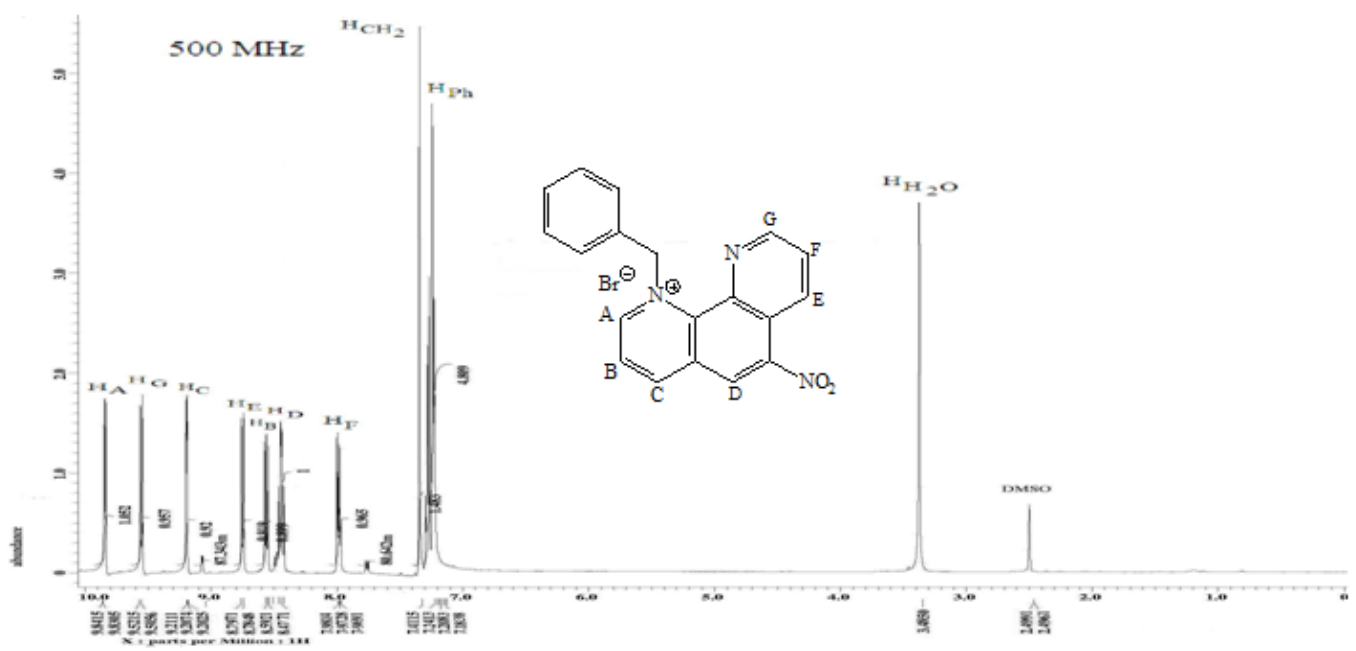

Fig 11. The ${ }^{1} \mathrm{H}-\mathrm{NMR}$ spectrum of (1)-N-benzyl-6-nitro-1,10-phenanthrolinium bromide 6

\section{Synthesis of (1)-N-Benzyl-6-nitro-1,10-pheanthro linium chloride (5)}

A solution of 5-nitro-1,10-phenathroline hydrate 2 compound ( $0.45 \mathrm{~g} ; 2 \mathrm{mmol})$ and benzyl chloride $(1.26 \mathrm{~g}$, $10 \mathrm{mmol})$ in acetone $(25 \mathrm{~mL})$ was refluxed for $18 \mathrm{~h}$. The resulting mixture was cooled, then the precipitate which formed was filtered and washed with acetone. Recrystallization of product was conducted with dichloromethane : diethyl ether (1:1) to give (1)- $N$ benzyl-6-nitro-1,10-phenanthrolinium chloride $\mathbf{5}$ compound (purple solid, $0.58 \mathrm{~g}, 82.50 \%$ ) and m.p: $=223-225{ }^{\circ} \mathrm{C}$. FT-IR $\left(\mathrm{KBr}, \mathrm{v}, \mathrm{cm}^{-1}\right): 3448.5\left(\mathrm{H}_{2} \mathrm{O}\right.$; hydrogen bonding from hydrate), 3066.6, 2854.5, 1607.2, 1593.1, 1525.2, 1500.5, 1454.2, 1415.7, 1358.8, $1230.5,1157.2,833.2,810.0,732.0,636.5$ and 617.2 . ${ }^{1} \mathrm{H}-\mathrm{NMR}$ (DMSO-d6; $500 \mathrm{MHz}, \mathrm{TMS}$ ) $\delta$ (ppm): 9.84-9.83 $\left(1 \mathrm{H}, \mathrm{m}, \mathrm{H}_{\mathrm{A}}\right), 9.56-9.54\left(1 \mathrm{H}, \mathrm{m}, \mathrm{H}_{\mathrm{G}}\right), 9.20-9.19(1 \mathrm{H}, \mathrm{m}$, $\left.\mathrm{H}_{\mathrm{C}}\right), 8.75-8.74\left(1 \mathrm{H}, \mathrm{m}, \mathrm{H}_{\mathrm{E}}\right)$; 8.58-8.52 $\left(1 \mathrm{H}, \mathrm{m}, \mathrm{H}_{\mathrm{B}}\right), 8.44-$ $8.43\left(1 \mathrm{H}, \mathrm{m}, \mathrm{H}_{\mathrm{B}}\right), 8.00-7.99\left(1 \mathrm{H}, \mathrm{m}, \mathrm{H}_{\mathrm{F}}\right), 7.34(2 \mathrm{H}, \mathrm{s}$, $\left.\mathrm{CH}_{2}\right)$ and $7.26-7.24\left(5 \mathrm{H}, \mathrm{m}, \mathrm{H}_{\mathrm{ph}}\right)$.

\section{Synthesis of (1)-N-Benzyl-6-nitro-1,10-phenathro linium bromide (6)}

A solution of 5-nitro-1,10-phenathroline hydrate 2 $(0.45 \mathrm{~g} ; 2 \mathrm{mmol})$ was refluxed with benzyl bromide $(1.71 \mathrm{~g}, 10 \mathrm{mmol})$ in acetone $(25 \mathrm{~mL})$. The mixture was stirred at $58{ }^{\circ} \mathrm{C}$ for $16 \mathrm{~h}$. The resulting mixture was cooled, then the precipitate which formed was filtered, and washed with acetone. Recrystallization of product was conducted with dichloromethane : diethyl ether (1:1) to give (1)- $N$-benzyl-6-nitro-1,10-phenathrolinium bromide 6 compound (pink solid, $0.66 \mathrm{~g}, 83.28 \%$ ), and m.p: $=224-225^{\circ} \mathrm{C}$. FT-IR $\left(\mathrm{KBr}, \mathrm{v}, \mathrm{cm}^{-1}\right)$ : $3447.6\left(\mathrm{H}_{2} \mathrm{O}\right.$; hydrogen bonding from hydrate), 3050-3000, 2925.1, 1622.6, 1521.0, 1457.7, 1345.0, 1263.7, 1149.4, 856.5, 740.3, and 717.9; ${ }^{1} \mathrm{H}-\mathrm{NMR}$ (DMSO-d6, $500 \mathrm{MHz}, \mathrm{TMS}$ ) $\delta$ (ppm): 9.84-9.83 $\left(1 \mathrm{H}, \mathrm{m}, \mathrm{H}_{\mathrm{A}}\right)$ 9.52-9.50 $\left(1 \mathrm{H}, \mathrm{m}, \mathrm{H}_{\mathrm{G}}\right)$, 


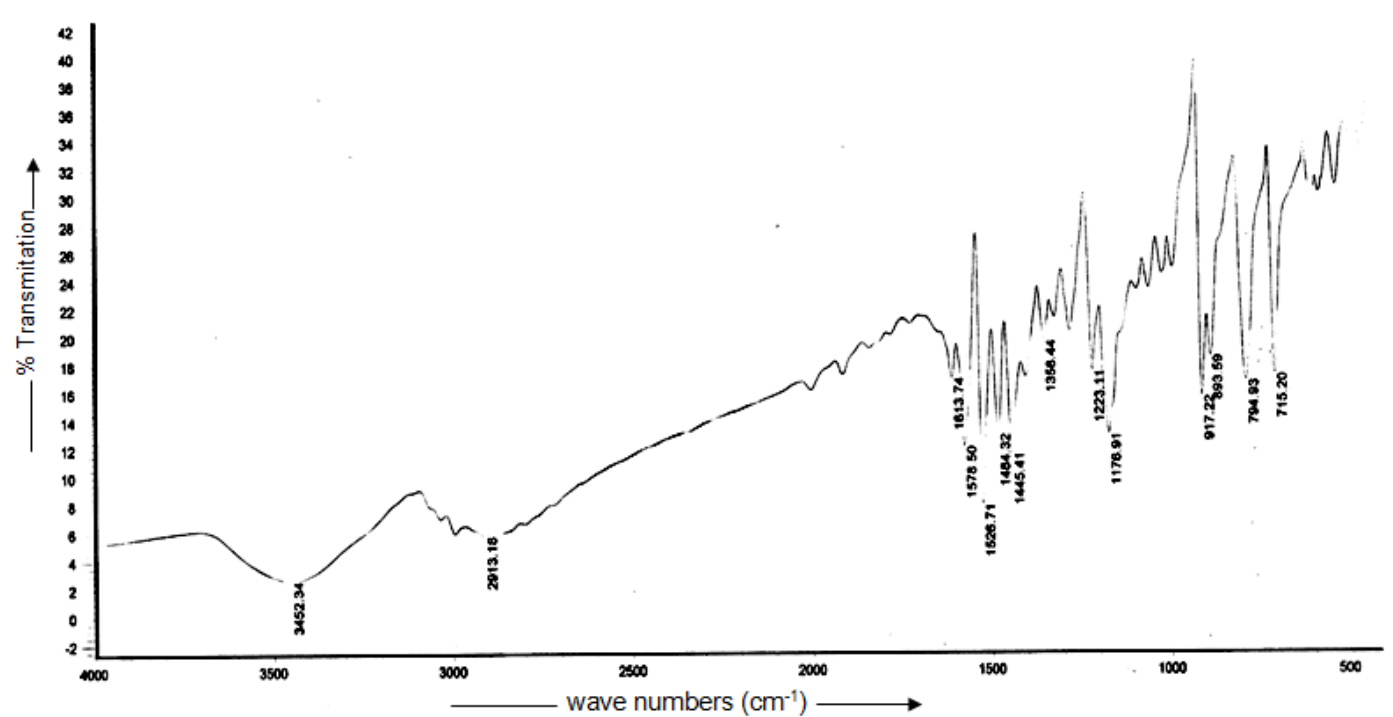

Fig 12. FTIR spectrum of (1)-N-benzyl-6-nitro-1,10-phenanthrolinium iodide 7

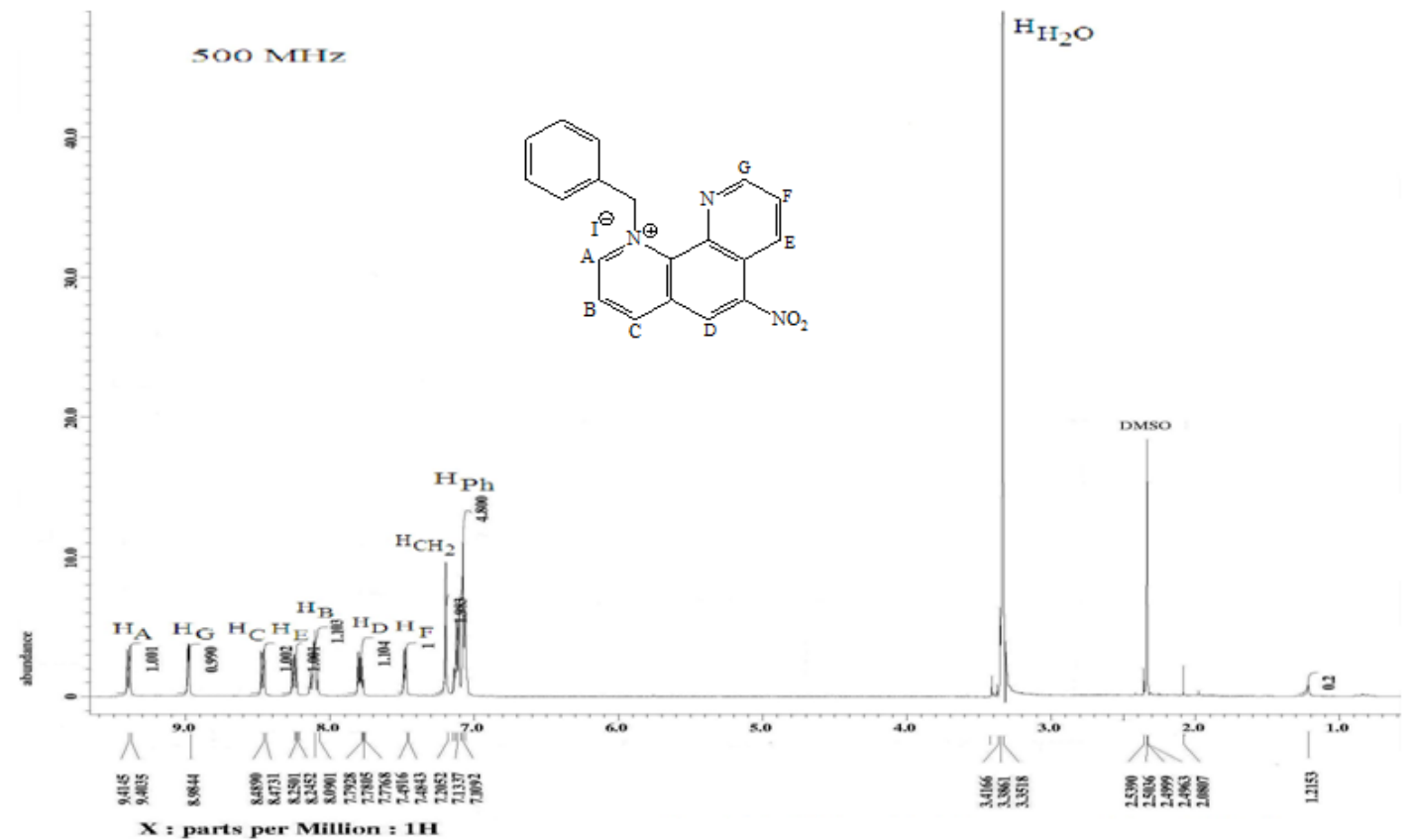

Fig 13. The ${ }^{1} \mathrm{H}-\mathrm{NMR}$ spectrum of (1)-N-benzyl-6-nitro-1,10-phenanthrolinium iodide 7

9.21-9.20 $\left(1 \mathrm{H}, \mathrm{m}, \mathrm{H}_{\mathrm{C}}\right), 8.79-8.78\left(1 \mathrm{H}, \mathrm{m}, \mathrm{H}_{\mathrm{E}}\right), 8.59(1 \mathrm{H}$, $\left.\mathrm{m}, \mathrm{H}_{\mathrm{B}}\right), 8.47\left(1 \mathrm{H}, \mathrm{m}, \mathrm{H}_{\mathrm{D}}\right) 7.98-7.96\left(1 \mathrm{H}, \mathrm{m}, \mathrm{H}_{\mathrm{F}}\right), 7.41(2 \mathrm{H}$, $\left.\mathrm{s}, \mathrm{CH}_{2}\right)$ and $7.24-7.18\left(5 \mathrm{H}, \mathrm{m}, \mathrm{H}_{\mathrm{Ar}}\right)$.

\section{Synthesis of (1)-N-Benzyl-6-nitro-1,10-pheanthro linium iodide (7) compound}

A solution of 5-nitro-phenanthroline hydrate 2 $(0.45 \mathrm{~g} ; 2 \mathrm{mmol})$ and benzyl iodide $(10 \mathrm{mmol})$ in acetone $(25 \mathrm{~mL})$ was refluxed for $14 \mathrm{~h}$. The resulting mixture was cooled, then the precipitate which formed was filtered, and washed with acetone. Recrystallization of product was conducted with dichloromethane : diethyl ether (1:1) to give (1)- $N$-benzyl-6-nitro-1,10-pheanthrolinium iodide 7 compound (yellow solid, $0.76 \mathrm{~g}, 84.55 \%$, m.p: $\left.225-227{ }^{\circ} \mathrm{C}\right)$. FT-IR $\left(\mathrm{KBr}, \mathrm{v} ; \mathrm{cm}^{-1}\right): 3452.3\left(\mathrm{H}_{2} \mathrm{O}\right.$; hydrogen bonding from hydrate), 3050-3000, 2913.2, $1613.7,1578.5,1526.7,1484.4,1445.4,1223.1$, 1178.9, 917.2, 893.5, 794.9 and 715.2; ${ }^{1}$ H-NMR (DMSO-d6; $500 \mathrm{MHz}$, TMS) $\delta$ (ppm): 9.41-9.40 $\left(1 \mathrm{H}, \mathrm{m}, \mathrm{H}_{\mathrm{A}}\right) 8.98\left(1 \mathrm{H}, \mathrm{m}, \mathrm{H}_{\mathrm{G}}\right), 8.48-8.47\left(1 \mathrm{H}, \mathrm{m}, \mathrm{H}_{\mathrm{C}}\right)$, 8.25-8.24 $\left(1 \mathrm{H}, \mathrm{m}, \mathrm{H}_{\mathrm{E}}\right), 8.09\left(1 \mathrm{H}, \mathrm{m}, \mathrm{H}_{\mathrm{B}}\right), 7.79-7.78$ $\left(1 \mathrm{H}, \mathrm{m}, \mathrm{H}_{\mathrm{D}}\right), 7.49-7.48\left(1 \mathrm{H}, \mathrm{m}, \mathrm{H}_{\mathrm{Ar}}\right), 7.20\left(2 \mathrm{H}, \mathrm{s}, \mathrm{CH}_{2}\right)$ and 7.13-7.03 $\left(5 \mathrm{H}, \mathrm{m}, \mathrm{H}_{\mathrm{Ar}}\right)$. 


\section{Biology Activity}

Parasites were cultured according to method described by Trager and Jensen [13] with modification [14-15]. FCR-3 was considered as a chloroquino resistant strain and D10 were considered as a chloroquine sensitive strain. Culture medium was replaced daily and the cultures were synchronized by $5 \%$ D-sorbitol lysis (Merck, Darmstadt, Germany). The method used for in vitro antimalarial activity testing was adapted from visual method. The molecules were tested 3 times in triplicate in 96-well plates (TPP, Switzerland) with cultures at ring stage at $0.5-1.0 \%$ parasitemia (hematocrit: 1\%). For each test, the parasite cultures were incubated with the chemicals at decreasing concentrations for 24 and $72 \mathrm{~h}$. The first dilution of the product $(10 \mathrm{mg} / \mathrm{mL})$ was performed with dimethyl sulphoxide (DMSO, Merck), and the following with RPMI 1640. Parasite growth was estimated by coloring with giemsa $(10 \%)$ for $30 \mathrm{sec}$ and calculated by $\beta$-caunter. The parasite control in the presence without chemicals (mean of the corresponding wells was referred to as $100 \%$ ). Concentrations inhibiting $50 \%$ of the parasite $\left(\mathrm{IC}_{50}\right)$ were determined by SPPS 13.0 software. The $\mathrm{IC}_{50}$ is indicate the antiplasmodial activity of chemicals compound that are determined by probit analysis method with percent concentration inhibition versus chemical doses.

\section{RESULT AND DISCUSSION}

Synthesis of (1)- $N$-alkyl- and (1)- $N$-benzyl-5-nitro1,10-phenanthrolinium salts compounds are shown in Fig. 1. Synthesis of 5-nitro-1,10-phenanthroline hydrate 2 derivatives from 1,10-phenanthroline monohydrate 1 through two steps to give phenanthroline 3-7 were presented in Fig. 1. The (1)-N-alkyl- and (1)-N-benzyl-5nitro-1,10-phenanthrolinium salts compounds were synthesized from 1,10-phenanthroline monohydrate 1 compound through two steps reaction i.e. (a) nitration reaction of 1,10-phenanthroline monohydrate 1 using $\mathrm{HNO}_{3}$ reagent and $\mathrm{H}_{2} \mathrm{SO}_{4}$ as catalyst, (b) alkylation and benzylation of 5-nitro-1,10-phenanthroline hydrate 2 using DMS, DES, benzyl chloride, benzyl bromide, and benzyl iodide to give (1)- $N$-methyl-6-nitro-1,10phenanthrolinium sulphate 3 , (1)- $N$-ethyl-6-nitro-1,10phenanthrolinium sulphate 4, (1)- $N$-benzyl-6-nitro-1,10phenanthrolinium chloride 5, (1)-N-benzyl-6-nitro-1,10phenanthrolinium bromide $\mathbf{6}$, and (1)- $N$-benzyl-6-nitro1,10-phenanthrolinium iodide 7 compound, and the scheme of reaction is shown in Fig. 1.

Synthesis of 5-nitro-1,10-phenanthroline hydrate 2 was conducted from 1,10-phenanthroline monohydrate 1 through nitration reaction using $\mathrm{HNO}_{3}$ reagent and $\mathrm{H}_{2} \mathrm{SO}_{4}$ as catalyst. The product of nitration reaction was characterized by FTIR, ${ }^{1} \mathrm{H}-\mathrm{NMR}$ and mass spectrometry. The FTIR spectrum showed pick in 1519.8 and $1357.8 \mathrm{~cm}^{-1}$ indicated the product of nitration has $-\mathrm{NO}_{2}$ functional group. Absorption bands of $\mathrm{C}-\mathrm{N}$ at $1176.5 \mathrm{~cm}^{-1}$ corroborate the existence of the 5-nitro-1,10-phenanthroline hydrate 2 compound as product of this reaction. The ${ }^{1} \mathrm{H}-\mathrm{NMR}$ spectrum of 5-nitro-1,10-phenanthroline hydrate 2 shows four signals at: 9.3, 9.0-8.6, 8.0-7.6 and $3.0 \mathrm{ppm}$, respectively, which are assigned to $\mathrm{H}_{A}(2 \mathrm{H}), \mathrm{H}_{B}(2 \mathrm{H})$, $\mathrm{H}_{\mathrm{B}}(3 \mathrm{H})$, and $\mathrm{H}_{2} \mathrm{O}$ as hydrogen bonding protons from hydrate. The ${ }^{1} \mathrm{H}-\mathrm{NMR}$ and mass spectrum of 5 -nitro1,10-phenanthroline hydrate 2 as product showed in Fig. 2 and 3, respectively.

Synthesis of (1)-N-methyl-6-nitro-1,10phenanthrolinium sulphate 3 compound was conducted from 5-nitro-1,10-phenanthroline hydrate 2 by DMS reagent in acetone to give white solid compound (m.p $192-194{ }^{\circ} \mathrm{C}$ ) in $81.26 \%$ yield. The structure of (1)- $N$-methyl-6-nitro-1,10-phenanthrolinium sulphate 3 was determined by FTIR and ${ }^{1} \mathrm{H}-\mathrm{NMR}$ spectrum. The FTIR spectrum showed typical spectra at $1384.8 \mathrm{~cm}^{-1}$ to indicate presence of the methyl group, while the ${ }^{1} \mathrm{H}$-NMR spectrum showed signal of singlet peak at $\delta 5.2 \mathrm{ppm}(3 \mathrm{H})$ assigned to the methyl group too. The FTIR and ${ }^{1} \mathrm{H}-\mathrm{NMR}$ spectrums are shown in Fig. 4 and 5 , respectively.

The compound of (1)- $N$-ethyl-6-nitro-1,10phenanthrolinium sulphate 4 was synthesized through ethylation reaction with DES in acetone by reflux for $12 \mathrm{~h}$ to give the salt compound (m.p 206-207 ${ }^{\circ} \mathrm{C}$; $76.09 \%$ ). The structure of product was determined by FTIR and ${ }^{1} \mathrm{H}-\mathrm{NMR}$ spectrum. Similarly, the FTIR spectrum of (1)- $\mathrm{N}$-ethyl-6-nitro-1,10-phenanthrolinium sulphate 4 compound showed typical spectrum at 1454.2 and $1365.1 \mathrm{~cm}^{-1}$, respectively, assigned to the methyl and methylene groups, while the ${ }^{1} \mathrm{H}-\mathrm{NMR}$ spectrum of (1)- $N$-ethyl-6-nitro-1,10-phenanthrolinium sulphate 4 compound showed triplet peak at $\delta 1.18$ $1.15(3 \mathrm{H})$ and quartet peak at $\delta 3.51-3.46(2 \mathrm{H})$, respectively, to indicate presence of methyl and methylene groups. The FTIR and ${ }^{1} \mathrm{H}-\mathrm{NMR}$ spectrums are shown in Fig. 6 and 7, respectively.

Synthesis of (1)- $N$-benzyl-6-nitro-1,10phenanthrolinium chloride 5 was conducted from 5nitro-phenanthroline hydrate 2 compound with benzyl chloride reagent in acetone which refluxing for $18 \mathrm{~h}$ to give purple solid (m.p: $=223-225^{\circ} \mathrm{C}$ ) in $82.50 \%$ yield. The structure of (1)- $N$-benzyl-6-nitro-1,10phenanthrolinium chloride 5 was determined by FT-IR and ${ }^{1} \mathrm{H}$-NMR spectrum. The FT-IR spectrum (Fig. 8) of (1)- $N$-benzyl-6-nitro-1,10-phenanthrolinium chloride $\mathbf{5}$ compound showed a spectra at $1454.2 \mathrm{~cm}^{-1}$ corresponding to $-\mathrm{CH}_{2-}$ from benzyl group. In confirmation, the $\mathrm{CH}_{2}$ proton revealed at $\delta 7.34 \mathrm{ppm}$ in 
Table 2. Parasite growth inhibition and $\mathrm{IC}_{50}$ of 5-nitro-1,10-phenanthroline 2 on FCR3 strain calculated for $72 \mathrm{~h}$ of incubation time

\begin{tabular}{cccccc}
\hline \multirow{2}{*}{$\begin{array}{c}\text { Concentration } \\
(\mathrm{ng} / \mathrm{mL})\end{array}$} & \multicolumn{5}{c}{ \%Inhibition (mean $\pm S D)$} \\
\cline { 2 - 6 } & Compound 3 & Compound 4 & Compound 5 & Compound 6 & Compound 7 \\
\hline 25 & $39.68 \pm 8.70$ & $N D$ & $26.36 \pm 10.38$ & $N D$ & $25.71 \pm 7.98$ \\
50 & $33.00 \pm 14.66$ & 0.00 & $32.94 \pm 6.00$ & $49.26 \pm 9.69$ & $21.47 \pm 7.51$ \\
100 & $35.57 \pm 3.12$ & $8.59 \pm 0.47$ & $41.59 \pm 11.39$ & $57.11 \pm 4.02$ & $29.24 \pm 13.23$ \\
200 & $42.65 \pm 3.06$ & $23.03 \pm 2.45$ & $43.71 \pm 5.62$ & $69.08 \pm 3.32$ & $37.63 \pm 7.50$ \\
400 & $58.06 \pm 8.30$ & $35.94 \pm 2.26$ & $45.70 \pm 3.94$ & $80.15 \pm 1.86$ & $47.60 \pm 11.77$ \\
800 & $69.07 \pm 4.79$ & $82.91 \pm 4.52$ & $60.55 \pm 7.62$ & $93.92 \pm 2.17$ & $52.91 \pm 9.99$ \\
1600 & $N D$ & $N D$ & $N D$ & $96.93 \pm 1.32$ & $N D$ \\
\hline $\mathrm{IC}_{50}(\mu \mathrm{M})$ & $0.72 \pm 0.16$ & $0.67 \pm 0.05$ & $2.41 \pm 1.41$ & $0.17 \pm 0.05$ & $1.79 \pm 1.19$ \\
\hline$N D=$ not & & & & &
\end{tabular}

Table 3. Parasite growth inhibition and $\mathrm{IC}_{50}$ of 5 -nitro-1,10-phenanthroline 2 on $\mathrm{D} 10$ strain calculated for $72 \mathrm{~h}$ of incubation time

\begin{tabular}{|c|c|c|c|c|c|c|}
\hline \multirow{2}{*}{$\begin{array}{c}\text { Concentration } \\
(\mathrm{ng} / \mathrm{mL})\end{array}$} & \multicolumn{6}{|c|}{ \%Inhibition (mean $\pm S D$ ) } \\
\hline & Compound 3 & Compound 5 & Compound 6 & Compound 7 & $\begin{array}{c}\text { Conc. } \\
\text { (ng/mL) }\end{array}$ & Compound 4 \\
\hline 50 & $37.20 \pm 8.09$ & $53.11 \pm 5.62$ & $44.72 \pm 6.75$ & $59.17 \pm 2.35$ & 125 & 0.00 \\
\hline 100 & $45.36 \pm 6.87$ & $58.04 \pm 8.49$ & $70.07 \pm 3.17$ & $65.77 \pm 2.94$ & 250 & $11.48 \pm 5.04$ \\
\hline 200 & $53.75 \pm 2.37$ & $66.61 \pm 2.79$ & $77.76 \pm 0.15$ & $67.50 \pm 1.34$ & 500 & $30.48 \pm 6.29$ \\
\hline 400 & $61.12 \pm 5.77$ & $71.99 \pm 4.69$ & $89.10 \pm 1.26$ & $69.56 \pm 3.03$ & 1000 & $53.10 \pm 2.05$ \\
\hline 800 & $69.30 \pm 2.07$ & $83.24 \pm 3.38$ & $93.36 \pm 2.43$ & $80.65 \pm 2.87$ & 2000 & $89.55 \pm 1.04$ \\
\hline 1600 & $83.85 \pm 3.05$ & $93.72 \pm 2.45$ & $97.19 \pm 1.01$ & $94.93 \pm 0.11$ & - & - \\
\hline $\mathrm{IC}_{50}(\mu \mathrm{M})$ & $0.25 \pm 0.01$ & $0.16 \pm 0.05$ & $0.13 \pm 0.02$ & $0.07 \pm 0.01$ & & $1.28 \pm 0.05$ \\
\hline
\end{tabular}

$N D=$ not determined

its ${ }^{1} \mathrm{H}-\mathrm{NMR}$ spectrum (Fig. 9). The singlet signal at $\delta 7.34 \mathrm{ppm}$ is compatible with the proton signal of methylene group. The specific spectra of singlet signal at $\delta 7.34 \mathrm{ppm}$ was indicated proton of methylene $\left(-\mathrm{CH}_{2^{-}}\right)$ corresponding to the chemical shift of proton of methylene group calculated with ChemOffice Ultra 6 . The complete result showed in Fig. 9 and Table 1.

The benzylation of 5-nitro-phenanthroline hydrate 2 compound has been conducted using benzyl bromide reagent in acetone which refluxing for $16 \mathrm{~h}$ to give pink solid of (1)-N-benzyl-6-nitro-1,10-phenathrolinium bromide 6 compound (m.p: $=224-225{ }^{\circ} \mathrm{C}$ ) in $83.28 \%$ yield. The structure of (1)-N-benzyl-6-nitro-1,10phenanthrolinium bromide 6 compound was determined by FT-IR and ${ }^{1} \mathrm{H}-\mathrm{NMR}$ spectrometry. The FT-IR spectrum (Fig. 10) showed typical spectra in $v 1457.7$ $\mathrm{cm}^{-1}$ to indicate presence of the methylene group, while the ${ }^{1} \mathrm{H}-\mathrm{NMR}$ spectrum (Fig. 11) showed singlet peak at $\delta 7.41 \mathrm{ppm}$, assigned to the methylene group too.

The benzylation of 5-nitro phenanthroline hydrate 2 using benzyl iodide was carried out giving (1)-N-benzyl6-nitro-1,10-phenanthrolinium iodide 7 compound. Treatment of (1)-N-benzyl-6-nitro-1,10-phenanthrolinium iodide 7 in acetone solvent was refluxed for $14 \mathrm{~h}$ to give yellow solid (m.p: $225-227^{\circ} \mathrm{C}$ ) in $84.55 \%$ yield. The $\mathrm{CH}_{2}$ group from (1)-N-benzyl-6-nitro-1,10-phenanthrolinium iodide 7 revealed a spectra at $1445.4 \mathrm{~cm}^{-1}$ in its FT-IR spectrum, while the ${ }^{1} \mathrm{H}-\mathrm{NMR}$ spectrum showed a singlet at $\delta 7.20 \mathrm{ppm}$ corresponding to proton of methylene group. The FT-IR and ${ }^{1} \mathrm{H}-\mathrm{NMR}$ spectrums are shown in Fig. 13 and 14.

Two strains of $P$. falciparum were used to evaluate the in vitro antiplasmodial activities of compounds (3)-(7): the chloroquine-resistant FCR3 and sensitive D10 strains. The results are summarized in Tables 2 and 3. The antiplasmodial activity of (1)-Nalkyl- and (1)-N-benzyl-6-nitro-1,10-phenanthrolinium showed that (1)-N-methyl-6-nitro-1,10phenanthrolinium sulphate 3 , (1)- $N$-ethyl-6-nitro-1,10phenanthrolinium sulphate 4, (1)- $N$-benzyl-6-nitro-1,10phenanthrolinium chloride 5, (1)- $N$-benzyl-6-nitro-1,10phenanthrolinium bromide 6 and (1)-N-benzyl-1,10-6nitro-phenanthrolinium iodide 7 were active against $P$. falciparum FCR3 with an $\mathrm{IC}_{50} 0.72 \pm 0.16,0.67 \pm 0.05$, $2.41 \pm 1.41,0.17 \pm 0.05$ and $1.79 \pm 1.19 \mu \mathrm{M}$, respectively, and $\mathrm{D} 10$ strains with an $\mathrm{IC}_{50} 0.25 \pm 0.01$, $1.28 \pm 0.05,0.16 \pm 0.05,0.13 \pm 0.02$, and $0.07 \pm 0.01$, respectively. The result of antiplasmodium evaluation to all 5-nitro-1,10-phenanthroline hydrate 2 derivatives toward FCR-3 and D10 strain of $P$. falciparum were presented in Table 2 and 3, completely. In Tables 1 and 2 , it is clear that the higher the concentration of a given drugs compound, the higher the percents inhibition of parasite growth. Similar to at the low concentrations have low percents of inhibition of parasite growth. 
The percentage of inhibition of the parasitic growth following the study of an each concentration of compounds was evaluated. A compounds proves to be interesting if this inhibition is total, in other words, at the high concentration (1600 ng/L) causes an inhibition of more than $90 \%$ of the parasitic growth. Treatment with (1)-N-benzyl-6-nitro-1,10-phenanthrolinium bromide $\mathbf{6}$ compound significantly inhibited parasitemia of $P$. falciparum FCR3 and D10 strains. Based on the Table 1 showed having the highest antiplasmodial activity in FCR-3 strain is (1)-N-benzyl-6-nitro-1,10phenanthrolinium bromide $\mathbf{6}$ compound to equal $0.17 \pm 0.05$, while in Table 2 showed the (1)-N-benzyl-6nitro-1,10-phenanthrolinium iodide 7 compound having the highest antiplasmodial activity at D10 strain to equal $0.07 \pm 0.01 \mu \mathrm{M}$.

\section{CONCLUSION}

The 5-nitro-1,10-phenanthroline hydrate 2 derivatives compounds i.e. (1)- $N$-methyl-6-nitro-1,10phenanthrolinium sulphate 3 , (1)- $N$-ethyl-6-nitro-1,10phenanthrolinium sulphate 4, (1)- $N$-benzyl-6-nitro-1,10phenanthrolinium chloride 5 , (1)- $N$-benzyl-6-nitro-1,10phenanthrolinium bromide 6 , and (1)- $N$-benzyl-6-nitro1,10-phenanthrolinium iodide $\mathbf{7}$ compounds were synthesized, characterized, and evaluated of in vitro antiplasmodial activity. The result of antiplasmodium evaluation of 5-nitro-1,10-phenanthroline hydrate 2 derivatives having the highest antiplasmodial activity in FCR-3 strain is (1)- $N$-benzyl-6-nitro-1,10phenanthrolinium bromide $\mathbf{6}$ compound to equal $0.17 \pm 0.05$, while in the D10 strain having the highest antiplasmodial activity is (1)-N-benzyl-6-nitro-1,10phenanthrolinium iodide $\mathbf{7}$ compound to equal $0.07 \pm 0.01 \mu \mathrm{M}$.

\section{ACKNOWLEDGEMENT}

The study was funded by Postgraduate Research Grant from Minister of Education, Indonesian Government and $2^{\text {nd }}$ Research Grant from Indonesian Toray Science Foundation, ITSF-Indonesia. We are also grateful to PT. Konimex Indonesia for providing the chloroquine diposphate use in these tests.

\section{REFERENCES}

1. Daily, J.P., 2006, J. Clin. Pharmacol., 46, 12, 1487-1497.

2. Tatu, U., Jain, S., and Priya, P.P., 2005, J. Biosci., $30,5,567-571$.

3. Mahmoudi, N., Ortiz, J.V.J., Ciceron, L., Galvez, J., Mazier, D., Danis, M., Derouin, F., and Domenech R.G., 2006, J. Antimicrob. Chemother., 57, 3, 489497.

4. Nuri, Dachlan, Y.P., Santosa, M.H., Zaini, N.C., Widyawaruyanti, A., dan Sjafruddin, 2005, Majalah Farmasi Airlangga, 5, 3, 88-90.

5. Fidock, D.A., Rosenthal, P.J., Croft, S.L., Brun, R., and Nwaka, S., 2004, Nat. Rev. Drug Discovery, 3, 509-520.

6. Kayembe, J.S., Taba, K.M., Ntumba, K., Tshiongo, M.T.C., and Kazadi, T.K., 2010, J. Med. Plants Res., 4, 11, 991-994.

7. Olumese, P., 2005, Acta Trop., 95, 265-269.

8. Yapi, A.D., Mustofa, M., Valentin, A., Chavignon. O., Teulade., J., Mallie, M., Chapat, J., and Blace, Y., 2000, Chem. Pharm. Bull., 48, 12, 1886-1889.

9. Yapi, A.D., Valentin, A., Chezal, J.M., Chavignon. O., Chaillot, B., Gerhardt, R., Teulade, J.C., and Blace, Y., 2006, Arch. Pharm., 339, 4, 201-206.

10. Widjayanti, M.A., Solikhah, E.N., Tahir, I., Hadanu, R., Jumina, Supargiono, and Mustofa, 2006, J. Health Sci., 52, 6, 794-799.

11. Mustofa, M., Yapi, A.D., Valentin, A., Tahir, I., 2003, Berkala IImu Kedokteran, 35, 2, 67-64.

12. Hadanu, R., Mastjeh, S., Jumina, Mustofa, Sholikhah, E.N., Wijayanti, M.A., and Tahir, I., 2007, Indo. J. Chem, 7, 1, 72-77.

13. Trager, W., and Jensen, J. B., 1976, Science, 193, 4254, 673-675.

14. Benoit, F., Valentin, A., Pelissier, Y., Marion, C., Dakuyo, Z., Mallie, M., and Bastide, J.M., 1995, Trans. R. Soc. Trop. Med. Hyg., 89, 2, 217-218.

15. Desjardins, R.E., Canfield, C.J., Haynes, J.D., and Chulay, J.D., 1979, Antimicrob. Agents Chemother., 16, 6, 710-718. 